\title{
The Effect of Citrate and pH on Zinc Uptake by Wheat
}

\author{
P. Chairidchai and G.S.P. Ritchie*
}

\begin{abstract}
Zinc uptake by plants may be influenced by its reaction with organic ligands in the rhizosphere. Therefore, four experiments were conducted to examine the effects of an organic ligand (citrate) and pH on the uptake of $\mathrm{Zn}$ by wheat (Triticum aestivum $\mathrm{L}$. emend. Thell). Plants were grown for 21 to $28 \mathrm{~d}$ in a nutrient solution (containing $0-0.05$ $\mu \mathrm{mol} \mathrm{L}^{-1} \mathrm{Zn}$ ) in a temperature controlled tank, either in the absence or presence of citrate and at constant or variable pH (3.7-7.1). Dry matter weights of plant parts and $\mathrm{Zn}$ content in the shoots were determined. The activities of $\mathrm{Zn}$ in the nutrient solution were estimated. Shoot dry matter of the wheat plants in each experiment correlated well with either $\mathbf{Z}_{n_{T}} /\left[H^{+}\right]$or $\Sigma$ (moles $Z_{n_{N}} /$ charge)/ $\left./ H^{+}\right]\left(Z_{n_{r}}=\right.$ total $Z n, Z n_{1}=$ each zinc species). Both parameters could explain the relative shoot dry matter of the plants from all experiments in one equation $\left(y=A+B E^{-c x} ; r^{2}=0.79\right.$ and 0.77 , respectively). In the absence of citrate, shoot dry matter as well as $\mathrm{Zn}$ content increased with increasing $\mathrm{pH}$ and increasing total $\mathrm{Zn}$ concentrations in solution. In the presence of citrate, the shoot dry matter of wheat plants that were grown in nutrient solution with constant $\mathrm{pH}$ increased with the total $\mathrm{Zn}$ concentrations. However, the effect of the total $\mathrm{Zn}$ concentrations in the solution containing citrate with variable $\mathrm{pH}$ were less important than the effect of $\mathrm{pH}$.
\end{abstract}

$\mathrm{Z}$ NC ABSORPTION BY PLANTS usually increases with $\mathrm{Zn}$ concentration in solution (Carroll and Loneragan, 1968). However, other factors such as the presence of organic ligands and $\mathrm{pH}$ may also affect uptake (Chaudhry and Loneragan, 1972; Halvorson and Lindsay, 1977). Zinc absorption by plants usually decreases as the concentration of $\mathrm{H}^{+}$increases presumably because of the direct effect of $\mathrm{H}^{+}$toxicity and because of an indirect effect of competition between $\mathrm{Zn}^{2+}$ and $\mathrm{H}^{+}$ions for uptake sites on the root surface (Chaudhry and Loneragan, 1972). The effect of $\mathrm{pH}$ may be modified by the presence of organic ligands. In the presence of DTPA (diethylenetriamine pentaacetic acid) the uptake of $\mathrm{Zn}$ by maize was lower at pH 7.5 than at pH 5.2 (Halvorson and Lindsay, 1977). Ethylenediaminetetraacetic acid (EDTA) also depressed the uptake of $\mathrm{Zn}$ at $\mathrm{pH} 7.5$ but to a lesser extent. Both synthetic ligands complex Zn more strongly at $\mathrm{pH} 7.5$, and hence it was thought this was the cause of decreased uptake. However, the charge of the metal complex may have also influenced the extent of uptake. DeKock and Mitchell (1957) found that uptake of metal ions decreased as the charge of the complex with EDTA and DTPA increased.

Several different types of organic ligands exist in the rhizosphere (Stevenson and Ardakani, 1972) and some of these have been shown to increase the concentration of $\mathrm{Zn}$ in the soil solution (Chairidchai and Ritchie, 1990). There is only limited information on the effect of naturally occurring organic ligands on $\mathrm{Zn}$ absorption by plants. Hence, the objective of these experiments was to study the $\mathrm{Zn}$ absorption by wheat

Soil Science and Plant Nutrition, School of Agric., Univ. of Western Australia, Nedlands, Western Australia 6009. Received 7 June 1991. * Corresponding author.

Published in Agron. J. 85:322-328 (1993). plants in the presence and absence of citrate at various $\mathrm{pH}$ values.

\section{MATERIALS AND METHODS}

Four experiments were conducted to examine the effects of an organic ligand (citrate) and $\mathrm{pH}$ on the uptake of $\mathrm{Zn}$ by Gamenya wheat grown in a nutrient solution (Table 1) at 20 $\pm 1{ }^{\circ} \mathrm{C}$. Preliminary experiments indicated that the nutrient concentrations in Table 1 were adequate for plant growth.

\section{Experiment 1}

We investigated the hypothesis that increasing $\mathrm{pH}$ increases $\mathrm{Zn}$ uptake by wheat and the extent of the increase depends on the concentration of total soluble $\mathrm{Zn}\left(\mathrm{Zn}_{\mathrm{T}}\right)$. A complete factorial design was used to study the growth of wheat in nutrient solution containing three total soluble concentrations of $\mathrm{Zn}$ at $3 \mathrm{pH}$ values (Table 2). All treatments were in triplicate.

The seeds were germinated at $20 \pm 1^{\circ} \mathrm{C}$ on a wire mesh suspended above an aerated solution containing $250 \mu \mathrm{mol} \mathrm{L}-1$ $\mathrm{Ca}\left(\mathrm{NO}_{3}\right)_{2}, 2 \mu \mathrm{mol} \mathrm{L}^{-1} \mathrm{H}_{3} \mathrm{BO}_{3}$ and $4 \mu \mathrm{mol} \mathrm{L} \mathrm{L}^{-1}$ FeEDTA. Calcium and $\mathrm{B}$ are essential for root growth because they maintain the integrity of the root membrane (Haynes and Robbins, 1948 ). When the first leaf was fully open (7-10 d), three wheat plants were transferred to each 2.5-L pot containing an aerated, complete nutrient solution (Table 1). Zinc was supplied as pure metal dissolved in $0.27 \mathrm{M} \mathrm{HCl}$. Other reagents were analytical grade, and macronutrients were purified with dithizone and chloroform (Hewitt, 1952). Nutrient solutions were replaced every $24 \mathrm{~h}$.

Solution $\mathrm{pH}$ values from $4.0-5.2 \pm 0.05$ were created by the addition of $0.1 \mathrm{~mol} \mathrm{~L}^{-1} \mathrm{KOH}$ and adjusted to the desired values, once at the time the nutrient solution was replaced and then $10 \mathrm{~h}$ later. The amount of $\mathrm{K}$ added was always $<4 \%$ of the amount supplied by the complete nutrient solution.

\section{Experiment 2}

We studied the effect of increasing citrate concentration on the uptake of $\mathrm{Zn}$ by wheat at a constant $\mathrm{pH}$ of $5.5 \pm 0.1$ (Table 2). The experiment was an incomplete factorial of three total soluble concentrations of $\mathrm{Zn}$ and three concentrations of citrate. The experimental preparation and method were the same as in experiment 1 , except a plant density of five plants per 5 $\mathrm{L}$ pot was used and $\mathrm{pH}$ was controlled at $\mathrm{pH} 5.5 \pm 0.1$ by the presence of $1 \mathrm{mmol} \mathrm{L}^{-1} \mathrm{MES}$ (2-[N-morpholino] ethane sulphonic acid) as described by Ewing and Robson (1990). Citrate was added as the potassium salt. The nutrient solution

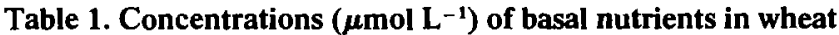
growth experiments.

\begin{tabular}{lcc}
\hline Nutrients & Exp. 1, 3, and 4 & Exp. 2 \\
\hline Macro & Concentration $\mu$ mol & $\mathrm{L}^{-1}-$ \\
$\mathrm{NH}_{4} \mathrm{NO}_{3}$ & 100 & $-\overline{3}$ \\
$\left.\mathrm{Ca}_{4} \mathrm{NO}_{3}\right)_{2} \cdot 4 \mathrm{H}_{2} \mathrm{O}$ & 500 & 400 \\
$\mathrm{KH}_{2} \mathrm{PO}_{4}$ & 20 & 20 \\
$\mathrm{~K}_{2} \mathrm{SO}_{4}$ & 200 & 150 \\
$\mathrm{MgCl}_{2} \cdot 6 \mathrm{H}_{2} \mathrm{O}$ & 100 & 100 \\
$\mathrm{CaCl}_{2}$ & - & 100 \\
$\left(\mathrm{NH}_{4}\right)_{2} \mathrm{SO}_{4}$ & - & 50 \\
$\mathrm{Micro}$ & & \\
$\mathrm{H}_{3} \mathrm{BO}_{3}$ & 2 & 2 \\
$\mathrm{CuSO}_{4} .5 \mathrm{H}_{2} \mathrm{O}$ & 0.1 & 0.1 \\
$\mathrm{MnSO}_{4} \cdot \mathrm{H}_{2} \mathrm{O}$ & 0.25 & 0.25 \\
$\mathrm{FeSO}_{4}$ & 4 & 4 \\
\hline
\end{tabular}


Table 2. Treatments imposed in Exp. 1-4.

\begin{tabular}{|c|c|c|c|c|c|c|c|}
\hline \multirow[b]{2}{*}{$\begin{array}{c}\text { Experiment } \\
\text { no. }\end{array}$} & \multicolumn{3}{|c|}{ Treatments } & \multicolumn{3}{|c|}{ Zn Speciationt } & \multirow{2}{*}{$\begin{array}{c}\Sigma(\mu m o l e s \neq \\
\text { Zn/charge }) \\
\left(\times 10^{3}\right)\end{array}$} \\
\hline & Total $\mathbf{Z n}$ & Total citrate & $\mathbf{p H}$ & $\begin{array}{c}\mathrm{Zn}^{2+} \\
\left(\times 10^{3}\right)\end{array}$ & $\begin{array}{c}\mathrm{ZnOH}^{+} \\
\left(\times 10^{6}\right)\end{array}$ & $\begin{array}{l}\text { Zncit }{ }^{-} \\
\left(\times 10^{3}\right)\end{array}$ & \\
\hline & \multicolumn{2}{|c|}{$\mu \mathrm{mol} \mathrm{L} \mathrm{L}^{-1}$} & & \multicolumn{3}{|c|}{$\mu \mathrm{mol} \mathbf{L}^{-1}$} & \\
\hline 1 & $\begin{array}{l}0.008 \\
0.015 \\
0.050\end{array}$ & $\begin{array}{l}\mathbf{0} \\
\mathbf{0} \\
\mathbf{0} \\
\mathbf{0} \\
\mathbf{0} \\
\mathbf{0} \\
\mathbf{0} \\
\mathbf{0} \\
\mathbf{0}\end{array}$ & $\begin{array}{l}4.0 \\
4.6 \\
5.2 \\
4.0 \\
4.6 \\
5.2 \\
4.0 \\
4.6 \\
5.2\end{array}$ & $\begin{array}{r}7.67 \\
7.67 \\
7.64 \\
14.4 \\
14.4 \\
14.4 \\
48.0 \\
48.0 \\
47.9\end{array}$ & $\begin{array}{r}1.91 \\
7.77 \\
29.54 \\
3.66 \\
14.64 \\
47.39 \\
12.21 \\
43.21 \\
139.9\end{array}$ & $\begin{array}{l}- \\
\overline{-} \\
\overline{-} \\
\overline{-} \\
\overline{-}\end{array}$ & $\begin{array}{c}3.84 \\
3.85 \\
3.85 \\
7.20 \\
7.21 \\
7.23 \\
24.0 \\
24.0 \\
24.1\end{array}$ \\
\hline 2 & $\begin{array}{l}0.004 \\
0.008 \\
0.015\end{array}$ & $\begin{array}{r}0 \\
0 \\
19 \\
0 \\
16 \\
50\end{array}$ & $\begin{array}{l}5.5 \\
5.5 \\
5.5 \\
5.5 \\
5.5 \\
5.5\end{array}$ & $\begin{array}{c}\mathbf{3 . 8 1} \\
7.62 \\
\mathbf{3 . 7 2} \\
14.3 \\
7.60 \\
\mathbf{3 . 6 8}\end{array}$ & $\begin{array}{l}24.63 \\
49.26 \\
23.98 \\
92.36 \\
49.04 \\
23.76\end{array}$ & $\begin{array}{l}\overline{-} \\
\overline{4.00} \\
\overline{6.85} \\
10.9\end{array}$ & $\begin{array}{r}1.93 \\
3.86 \\
5.88 \\
7.24 \\
10.7 \\
12.7\end{array}$ \\
\hline 3 & $\begin{array}{l}0.004 \\
0.008 \\
0.015\end{array}$ & $\begin{array}{r}0 \\
0 \\
25 \\
0 \\
20 \\
65\end{array}$ & $\begin{array}{l}4.7 \\
4.7 \\
4.5 \\
4.6 \\
4.5 \\
4.0\end{array}$ & $\begin{array}{r}3.84 \\
7.67 \\
6.17 \\
14.1 \\
11.9 \\
12.4\end{array}$ & $\begin{array}{r}3.82 \\
7.12 \\
3.66 \\
12.13 \\
7.45 \\
2.53\end{array}$ & $\begin{array}{l}- \\
\overline{1.21} \\
\overline{2.01} \\
1.08\end{array}$ & $\begin{array}{l}1.92 \\
3.84 \\
4.30 \\
7.21 \\
7.97 \\
7.30\end{array}$ \\
\hline 4 & 0.015 & $\begin{array}{r}0 \\
0 \\
0 \\
65 \\
65 \\
65\end{array}$ & $\begin{array}{l}4.7 \\
4.5 \\
3.7 \\
6.3 \\
6.9 \\
7.1\end{array}$ & $\begin{array}{c}14.4 \\
14.4 \\
14.4 \\
2.29 \\
2.18 \\
2.13\end{array}$ & $\begin{array}{r}13.26 \\
8.89 \\
1.45 \\
102.7 \\
337.6 \\
587.5\end{array}$ & $\begin{array}{r}- \\
- \\
\overline{12.5} \\
12.4 \\
12.2\end{array}$ & $\begin{array}{r}7.21 \\
7.20 \\
7.20 \\
13.71 \\
13.80 \\
13.30\end{array}$ \\
\hline
\end{tabular}

† Actual $\mathrm{Zn}$ concentrations have been multiplied by either $10^{3}$ or $10^{6}$.

$\ddagger \Sigma$ (the concentration of each $Z n$ species divided by its charge)

was replaced every 72 and $48 \mathrm{~h}$ in the first and second weeks of the experiment, respectively, and every $24 \mathrm{~h}$ thereafter.

\section{Experiment 3}

An incomplete factorial design was used to study the effect of citrate on $\mathrm{Zn}$ uptake by wheat at acidic $\mathrm{pH}$ values (4.3-4.7 $\pm 0.05)$ and three total concentrations of $\mathrm{Zn}$ considered to be deficient, moderately deficient and adequate for plant growth (Table 2). The experimental procedures were the same as in Exp. 1 except the plant density which was five plants per $5 \mathrm{~L}$ pot. Citric acid was the source of the citrate and $\mathrm{pH}$ variation; $\mathrm{Zn}$ was supplied as $\mathrm{Zn}\left(\mathrm{NO}_{3}\right)_{2}$.

\section{Experiment 4}

The effect of a wide range of $\mathrm{pH}$ (4.3-7.1) on $\mathrm{Zn}$ uptake by wheat in the presence and absence of citrate was studied using an incomplete factorial design (Table 2). The $\mathrm{Zn}$ concentration used was considered adequate for plant growth in the absence of citrate. The $\mathrm{pH}$ values were adjusted to the desired values \pm 0.05 (Table 2) with $5 \mathrm{~mL}$ of $0.05,0.1$, or $0.15 \mathrm{~mol} \mathrm{~L}^{-1} \mathrm{KOH}$ or $0,0.01$, or $0.15 \mathrm{~mol} \mathrm{~L}^{-1} \mathrm{HCl}$. Sources of $\mathrm{Zn}$ and citrate were the same as in Exp. 3. The experimental preparation and methods were the same as in experiment 1 except the plant density which was five plants per pot.

\section{Plant Analysis}

The plants in each of the experiments were harvested at 21 d, except for Exp. 2, in which the plants were harvested at 28 d. The total fresh weight of the plants was measured, and shoot and root dry weights determined after drying at $70 \pm 5^{\circ} \mathrm{C}$ for at least $72 \mathrm{~h}$. The shoots were digested in $\mathrm{HNO}_{3}$ and $\mathrm{HClO}$ (Johnson and Ulrich, 1959), and the concentration of $\mathrm{Zn}$ in
Table 3. Experiment 1. The effects of total $\mathrm{Zn}$ concentration in solution $\left[\mathrm{Zn}_{\mathrm{T}}\right]$, and $\mathbf{p H}$ on dry weight, $\mathrm{Zn}$ concentration and $\mathrm{Zn}$ content of wheat shoots, root fresh weight and the root/total fresh weight ratio.

\begin{tabular}{|c|c|c|c|c|c|c|}
\hline \multicolumn{2}{|c|}{ Treatments } & \multicolumn{3}{|c|}{ Shoots } & \multirow{2}{*}{$\begin{array}{c}\text { Root } \\
\text { fresh } \\
\text { wt. }\end{array}$} & \multirow{2}{*}{$\begin{array}{c}\text { Root } \\
\text { Tota } \\
\text { fresh } \\
\text { wt. }\end{array}$} \\
\hline$\left[\mathbf{Z n}_{\mathbf{T}}\right]$ & $\mathrm{pH}$ & dry wt. & $\begin{array}{l}\mathrm{Zn} \\
\text { conc. }\end{array}$ & $\underset{\text { content }}{\mathrm{Zn}}$ & & \\
\hline$\mu \mathrm{mol} \mathrm{L^{-1 }}$ & & g plant ${ }^{-1}$ & $\mu \mathrm{g} \mathrm{g}^{-1}$ & $\mu \mathrm{g}$ plant ${ }^{-1}$ & g plant ${ }^{-1}$ & \\
\hline 0.008 & $\begin{array}{l}4.0 \\
4.6 \\
5.2 \\
4.0 \\
4.6 \\
5.2 \\
4.0 \\
4.6 \\
5.2\end{array}$ & $\begin{array}{l}0.036 \\
0.070 \\
0.106 \\
0.046 \\
0.097 \\
0.175 \\
0.070 \\
0.106 \\
0.177\end{array}$ & $\begin{array}{l}14.10 \\
15.32 \\
14.91 \\
17.40 \\
15.47 \\
13.67 \\
21.37 \\
17.95 \\
17.75\end{array}$ & $\begin{array}{l}0.5 \\
1.0 \\
1.6 \\
0.8 \\
1.4 \\
2.4 \\
1.4 \\
1.9 \\
3.1\end{array}$ & $\begin{array}{l}0.41 \\
0.65 \\
0.68 \\
0.45 \\
0.67 \\
0.88 \\
0.37 \\
0.69 \\
0.92\end{array}$ & $\begin{array}{l}0.65 \\
0.52 \\
0.42 \\
0.58 \\
0.46 \\
0.39 \\
0.39 \\
0.45 \\
0.40\end{array}$ \\
\hline & & & & SSIS O & & \\
\hline $\begin{array}{c}{\left[\mathrm{Zn}_{\mathrm{r}}\right]} \\
\mathbf{p H} \\
\left.\mathbf{n}_{\mathrm{T}}\right] \times \mathrm{pH}\end{array}$ & & $\begin{array}{l}* * * \\
* * * \\
*\end{array}$ & $\begin{array}{l}\text { *** } \\
\text { NS } \\
\text { NS }\end{array}$ & $\begin{array}{l}* * * \\
\text { **** } \\
\text { NS }\end{array}$ & $\begin{array}{l}\text { NS } \\
\text { N*** } \\
\text { NS }\end{array}$ & $\begin{array}{l}* * * \\
* * * \\
* * *\end{array}$ \\
\hline
\end{tabular}

**** Significant at the 0.05 and 0.001 probability levels, respectively, NS, Not significant.

the digest was determined by atomic absorption spectrophotometry (Perkin Elmer 5000, Wilton, CT).

\section{Speciation Calculations}

The activities of the free $\mathrm{Zn}$ ion $\left(\mathrm{Zn}^{2+}\right)$, hydrolysed $\mathrm{Zn}$ $\left(\mathrm{ZnOH}^{+}\right)$and $\mathrm{Zn}$ citrate complex ( $\mathrm{Zncit}^{-}$) (Table 1 and 3$)$ in the nutrient solutions were calculated with a chemical equilibrium program TITRATOR (Cabaniss, 1987) and the thermodynamic stability constants at $20^{\circ} \mathrm{C}$ given by Lindsay (1979) 


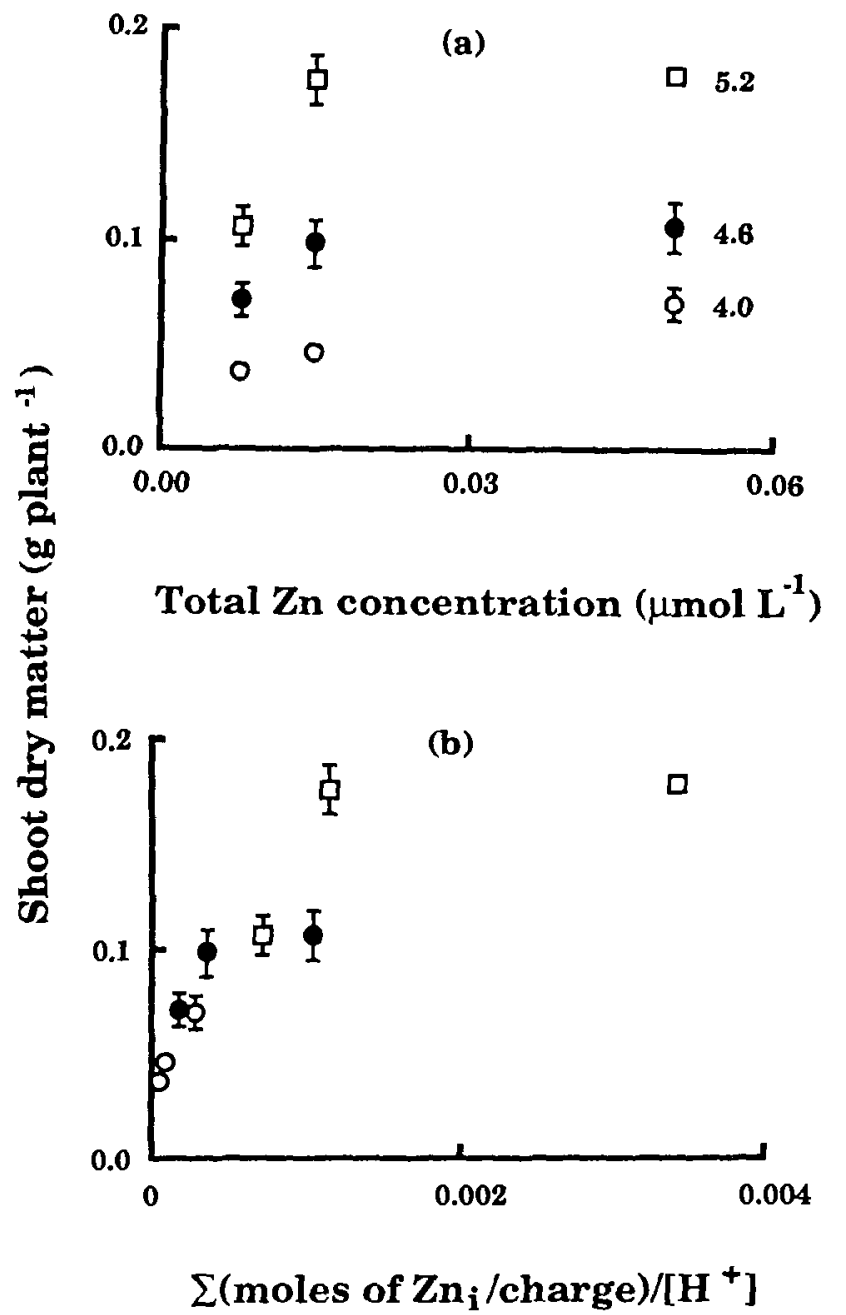

Fig. 1. The relationship between (a) total $\mathrm{Zn}$ concentration or (b) $\Sigma($ moles $\mathrm{Zn} /$ charge $) /\left[\mathrm{H}^{+}\right]$and shoot dry matter of wheat plants at pH $4.0(\bigcirc), 4.6(\odot)$ and $5.2(\square)$.

and Martell and Smith (1977). The calculations included reactions between all cations and anions in Table 2 as given in Lindsay (1979). Activity coefficients were calculated with the Guntelberg equation. Carbon dioxide concentrations were assumed to be equivalent to the atmospheric concentration because the solutions were continually aerated.

\section{Statistical Analysis}

The data were analyzed by estimating standard errors, Analysis of Variance, simple linear and non-linear regression $(y=A$ $\left.+B e^{-c x}\right)$, and stepwise multiple linear regression.

\section{RESULTS}

\section{Experiment 1}

Zinc deficiency symptoms first occurred on Day 13 on the youngest fully expanded blade of the plants grown with $0.008 \mu \mathrm{mol} \mathrm{L} \mathrm{L}^{-1} \mathrm{Zn}$ at $\mathrm{pH}$ 5.2. The symptom first appeared as a bruise patch in the middle of the leaves. One to $2 \mathrm{~d}$ later this area became necrotic and the necrotic area expanded to cover approximately $50 \%$ of the leaf area at harvest.

The plants grown in solutions at the other pHs at 0.008

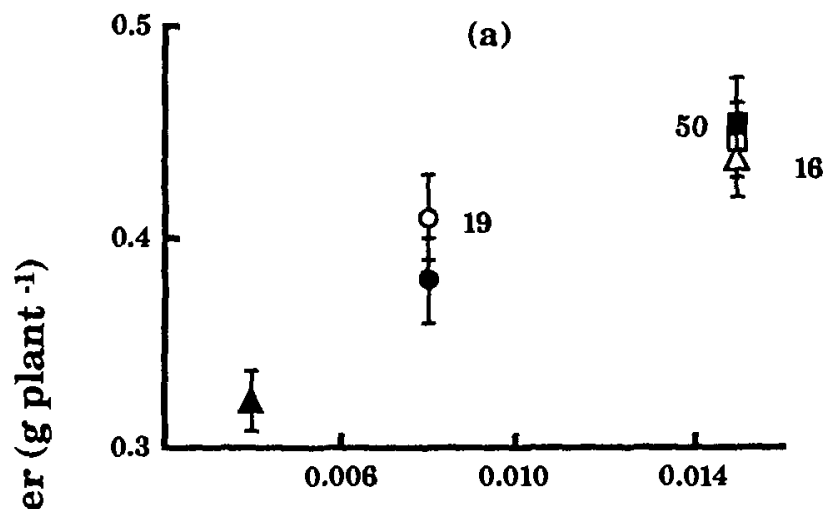

\section{Total $\mathrm{Zn}$ concentration $\left(\mu \mathrm{mol} \mathrm{L}^{-1}\right)$}

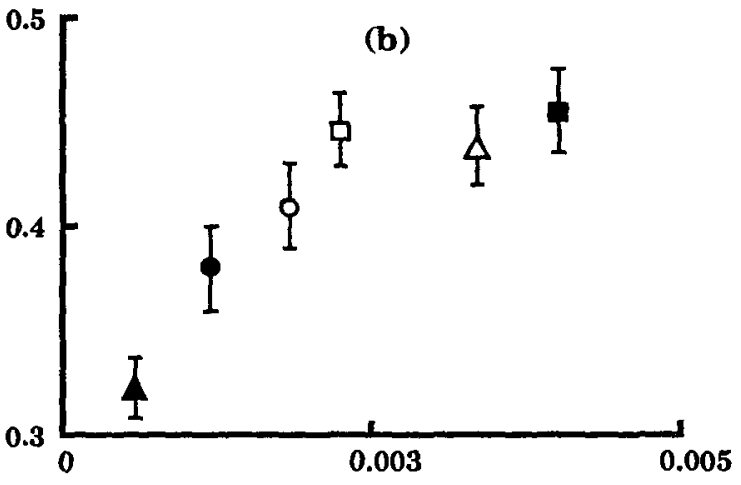

\section{$\Sigma\left(\right.$ moles of $\mathrm{Zn}_{\mathbf{i}} /$ charge $) /\left[\mathrm{H}^{+}\right]$}

Fig. 2. The relationship between (a) total $\mathrm{Zn}$ concentration or (b) $\Sigma$ (moles $\mathrm{Zn} /$ charge) $/\left[\mathrm{H}^{+}\right]$and shoot dry matter of wheat plants in the absence $(A, 0, \square)$ or presence of $16(\Delta), 19$ (O) or $50(\square) \mu \mathrm{mol} \mathrm{L}^{-1}$ of citrate at a constant solution pH of 5.5.

$\mu \mathrm{mol} \mathrm{L}^{-1} \mathrm{Zn}$ started developing deficiency symptoms 2 d later. The symptoms in these plants were more severe than at $\mathrm{pH} 5.2$ and the plants were stunted. Wheat grown in $0.015 \mu \mathrm{mol} \mathrm{L}^{-1} \mathrm{Zn}$ at $\mathrm{pH} 4.6$ developed symptoms on the same day, but the symptoms were not as severe. By harvest time only plants at 0.015 and $0.05 \mu \mathrm{mol} \mathrm{L}^{-1}$ $\mathrm{Zn}$ at $\mathrm{pH} 5.2$ were without symptoms.

The shoot dry matter content of the plants increased asymptotically with $\mathrm{Zn}$ supply and $\mathrm{pH}$ (Fig. 1a). Maximum growth occurred at $0.015 \mu \mathrm{mol} \mathrm{L} \mathrm{L}^{-1} \mathrm{Zn}$ at $\mathrm{pH} 5.2$ and 4.6 and at $0.05 \mu \mathrm{mol} \mathrm{L}^{-1} \mathrm{Zn}$ for $\mathrm{pH} 4.0$. The increase in yield was 2.5 times greater at $\mathrm{pH} 5.2$ than at $\mathrm{pH}$ 4.0. The difference in shoot dry matter could not be explained by a single effect of either the concentration in solution of $\mathrm{Zn}_{\mathrm{T}}, \mathrm{Z}$, or $\mathrm{H}^{+}$. However, there were good asymptotic correlations between shoot dry matter and $\mathrm{ZnOH}^{+}\left(r^{2}=0.84\right), \mathrm{Zn}_{\mathrm{T}} /\left[\mathrm{H}^{+}\right]\left(r^{2}=0.85\right)$ and the ratio of the sum of moles per charge of $\mathrm{Zn}$ species $\left(\mathrm{Zn}_{\mathrm{i}}\right)$ and $\mathrm{H}^{+}, \Sigma$ (moles $\mathrm{Zn}_{\mathrm{i}} /$ charge $) /\left[\mathrm{H}^{+}\right]\left(r^{2}=0.85\right.$, Fig. $\left.1 \mathrm{~b}\right)$.

The $\mathrm{Zn}$ concentration of the shoots increased with $\mathrm{Zn}$ supply (Table 3 ). At a constant supply of $\mathrm{Zn}$, the $\mathrm{Zn}$ concentration of the shoots did not vary significantly with 
Table 4. Experiment 2. Dry weight, $\mathrm{Zn}$ concentration, and $\mathrm{Zn}$ content of wheat shoots at various concentrations of $\mathrm{Zn}$, $\left[\mathrm{Zn}_{\mathrm{T}}\right]$, and citrate, $\left[\mathrm{cit}_{\mathrm{r}}\right]$, in solution at $\mathrm{pH}$ 5.5.

\begin{tabular}{|c|c|c|c|c|}
\hline \multicolumn{2}{|l|}{ Treatments } & \multicolumn{3}{|c|}{ Shoots $\dagger$} \\
\hline$\left[\mathbf{Z} \mathbf{n}_{\mathrm{T}}\right]$ & {$\left[\mathrm{cit}_{\mathbf{T}}\right]$} & dry wt. & $\mathrm{Zn}$ conc. & Zn content \\
\hline$-\mu \mathrm{mol} \mathrm{L-1}$ & - & g plant ${ }^{-1}$ & $\mu \mathrm{g} \mathrm{g}^{-1}$ & $\mu$ g plant $^{-1}$ \\
\hline $\begin{array}{l}0.004 \\
0.008 \\
0.008 \\
0.015 \\
0.015 \\
0.015\end{array}$ & $\begin{array}{l}\frac{-}{19} \\
\frac{19}{16} \\
50\end{array}$ & $\begin{array}{l}0.32 \mathrm{a} \\
0.38 \mathrm{ab} \\
0.41 \mathrm{bc} \\
0.45 \mathrm{bc} \\
0.44 \mathrm{c} \\
0.46 \mathrm{c}\end{array}$ & $\begin{array}{l}17.62 \\
18.62 \\
16.88 \\
20.97 \\
17.17 \\
19.48\end{array}$ & $\begin{array}{l}\mathbf{5 . 7 5} \\
8.98 \\
7.25 \\
9.65 \\
7.65 \\
9.35\end{array}$ \\
\hline & & \multicolumn{3}{|c|}{ Analysis of Variance } \\
\hline Treatments & & ** & NS & NS \\
\hline
\end{tabular}

* Significant at the 0.005 probability level, and NS, Not significant. $\dagger \mathrm{a}, \mathrm{b}$ All values within a column with no common letter are significantly different $(p<0.005)$.

$\mathrm{pH}(p<0.05)$. Dry matter yield was not well correlated with the $\mathrm{Zn}$ concentration of the shoots. Zinc content increased asymptotically with the ratio $\Sigma$ (moles $Z_{n_{i}}$ / charge) $/\left[\mathrm{H}^{+}\right]$and with $\mathrm{Zn}_{\mathrm{T}} /\left[\mathrm{H}^{+}\right]$(data not shown).

At a constant concentration of $\mathrm{Zn}$ supply, root fresh weight increased with $\mathrm{pH}$ in a similar manner to shoot growth (Table 3).

When root fresh weight was expressed as a proportion of total growth on a fresh weight basis, the proportion significantly decreased with $\mathrm{Zn}_{\mathrm{T}}$ when $\mathrm{pH}$ was held constant (Table 3). The percentage of total fresh weight attributable to roots decreased as the $\mathrm{Zn}$ content of the plants increased and reached a minimum value when $\mathrm{Zn}$ content was $\geq 1.5 \mu \mathrm{g}$ per plant (Table 3 ). A similar trend was also observed when the ratio of root to total fresh weight was plotted as a function of the ratio between the total moles per charge of $\mathrm{Zn}$ and $\mathrm{H}^{+}$, the minimum occurred at the ratio $\geq 5 \times 10^{-3}$.

\section{Experiment 2}

At harvest, the plants at $0.004 \mu \mathrm{mol} \mathrm{L^{-1 }} \mathrm{Zn}$ were stunted. These plants had $\mathrm{Zn}$ deficiency symptoms as explained in Exp. 1 However, the symptoms which occurred by Day 20 did not become severe.

The shoot dry matter content of the plants increased with $\mathrm{Zn}$ supply (Fig. 2a). However, there was no significant difference $(p<0.05)$ in shoot growth in the presence and absence of citrate at each $\mathrm{Zn}$ supply of 0.008 and $0.015 \mu \mathrm{mol} \mathrm{L}^{-1}$ (Table 4). Dry matter yield increased with the ratio of the sum of moles per charge of $\mathrm{Zn}$ species and $\mathrm{H}^{+}$and reached the maximum value at ratio $\geq 0.003$ (Fig. $2 b$; asymptotic regression, $r^{2}=$ $0.94)$. Dry matter yield was also asymptotically correlated with total $\mathrm{Zn}_{\mathrm{T}} /\left[\mathrm{H}^{+}\right]\left(r^{2}=0.92\right)$.

Shoot dry matter accounted for $75 \%$ of the variation in the $\mathrm{Zn}$ content of the shoots. The $\mathrm{Zn}$ concentrations of the shoots were similar in all treatments (Table 4).

\section{Experiment 3}

The first $\mathrm{Zn}$ deficiency symptom appeared on the youngest fully expanded blades of the plants at 0.004 $\mu \mathrm{mol} \mathrm{L}^{-1} \mathrm{Zn}$ on Day 12 , and it was very severe by harvest time. Two to $3 \mathrm{~d}$ later the symptoms also appeared on all the plants except those at $0.015 \mu \mathrm{mol} \mathrm{L}-1$ with no citrate. Among these plants, the ones at 0.015

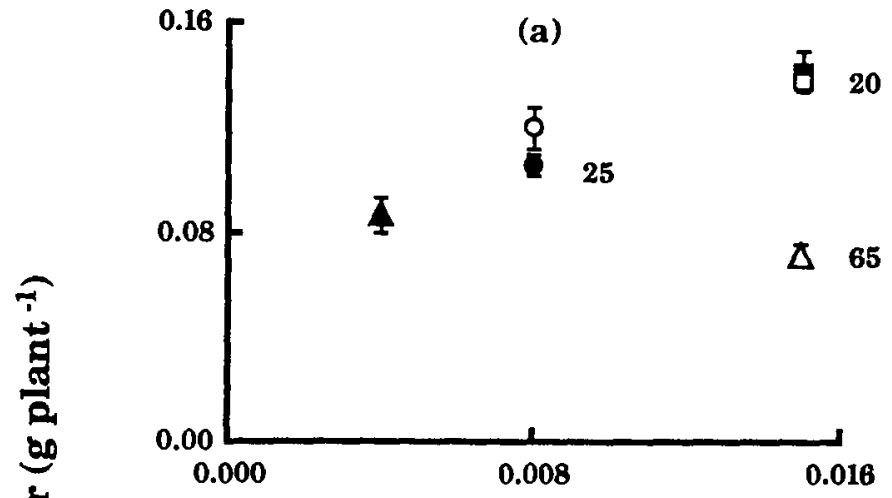

Total $\mathrm{Zn}$ concentration $\left(\mu \mathrm{mol} \mathrm{L} \mathbf{L}^{-1}\right)$

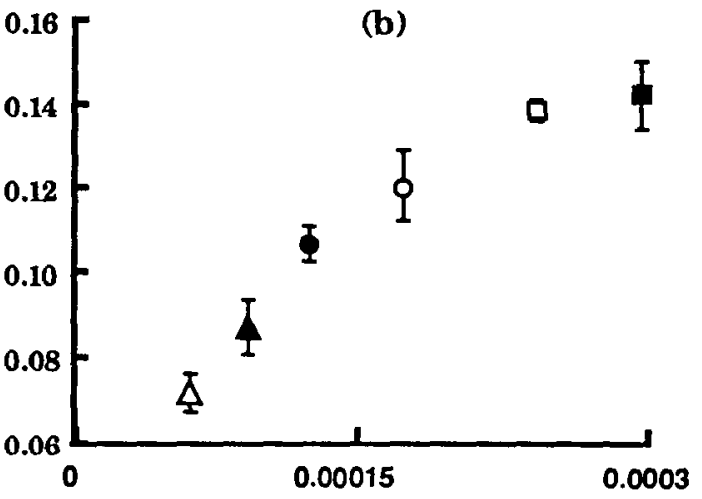

$\sum$ (moles of $\mathbf{Z n}_{\mathbf{i}} /$ charge $) /\left[\mathbf{H}^{+}\right]$

Fig. 3. The relationship between (a) total $\mathrm{Zn}$ concentration or (b) $\Sigma$ (moles $\mathrm{Zn} /$ charge) $/\left[\mathrm{H}^{+}\right]$and shoot dry matter of wheat plants in the absence $(A, O, \square)$ or presence of $20(\square), 25$ (O) or $65(\Delta) \mu \mathrm{mol} \mathrm{L}^{-1}$ of citrate at various pHs.

$\mu \mathrm{mol} \mathrm{L} \mathrm{L}^{-1} \mathrm{Zn}$ with $65 \mu \mathrm{mol} \mathrm{L^{-1 }}$ citrate became stunted and their roots were very short and produced a great amount of mucilage. The symptoms on the latter plants became as severe as those at lowest $\mathrm{Zn}$ concentration.

In the absence of citrate, shoot dry matter increased with total $\mathrm{Zn}$ supply (Fig. 3a). At 0.008 and $0.015 \mu \mathrm{mol}$ $\mathrm{L}^{-1} \mathrm{Zn}$, however, dry matter decreased when citrate was added (Table 5). In the presence of $25 \mu \mathrm{mol} \mathrm{L}^{-1}$ citrate at $0.008 \mu \mathrm{mol} \mathrm{L}-1 \mathrm{Zn}$, the dry matter decreased slightly, whereas there was a marked decrease $(p<0.05)$ when $65 \mu \mathrm{mol} \mathrm{L}{ }^{-1}$ citrate was added to $0.015 \mu \mathrm{mol} \mathrm{L}^{-1} \mathrm{Zn}$. Dry matter yield was well correlated with either $\mathrm{Zn}_{\mathrm{T}}$ / $\left[\mathrm{H}^{+}\right]\left(r^{2}=0.95 ; y=A+B e^{-\mathrm{cx}}\right)$ or the ratio between the sum of moles per charge of $\mathrm{Zn}$ species and $\mathrm{H}^{+}\left(r^{2}\right.$ $\left(r^{2}=0.98 ; y=A+B e^{-c x}\right.$; Fig. 3b). None of the $\mathrm{Zn}$ species in solution could adequately predict dry matter yield by fitting a single equation to a plot of yield versus the concentration of an individual $\mathrm{Zn}$ species. The combined effect of $\mathrm{Zn}^{2+}, \mathrm{Zncit}^{-}$, and $\mathrm{H}^{+}$however could account for $88 \%$ of the variation in the dry matter content by multiple regression.

In the absence of citrate, $\mathrm{Zn}_{\mathrm{n}}$ content and concentration of the plants both increased with $\mathrm{Zn}$ supply (Table 5). 
Table 5. Experiment 3 . Dry weight, $\mathrm{Zn}$ concentration and $\mathrm{Zn}$ content of wheat shoots at various concentrations of $\mathrm{Zn}$, $\left[Z n_{\mathrm{T}}\right]$, and citrate, $\left[\mathrm{cit}_{\mathrm{T}}\right]$, in solution.

\begin{tabular}{|c|c|c|c|c|c|}
\hline \multicolumn{3}{|c|}{ Treatments } & \multicolumn{3}{|c|}{ Shoots $\dagger$} \\
\hline$\left[\mathbf{Z n}_{\mathbf{r}}\right]$ & {$\left[\mathrm{cit}_{\mathrm{r}}\right]$} & pH & dry wt. & Zn conc. & Zn content \\
\hline$-(\mu \mathrm{mo}$ & ') - & & g plant ${ }^{-1}$ & $\mu \mathrm{g} \mathrm{g}^{-1}$ & $\mu \mathrm{g}$ plant $^{-1}$ \\
\hline \multirow[t]{2}{*}{$\begin{array}{l}0.004 \\
.0 .008 \\
0.008 \\
0.015 \\
0.015 \\
0.015\end{array}$} & $\begin{array}{l}- \\
\overline{25} \\
0 \\
20 \\
65\end{array}$ & $\begin{array}{l}4.7 \\
4.7 \\
4.5 \\
4.6 \\
4.5 \\
4.0\end{array}$ & $\begin{array}{l}0.09 \mathrm{a} \\
0.12 \mathrm{bc} \\
0.11 \mathrm{~b} \\
0.142 \mathrm{~d} \\
0.138 \mathrm{~cd} \\
0.071 \mathrm{a}\end{array}$ & $\begin{array}{c}7.01 \mathrm{a} \\
8.22 \mathrm{ab} \\
10.17 \mathrm{bc} \\
10.32 \mathrm{bc} \\
12.10 \mathrm{c} \\
7.58 \mathrm{a}\end{array}$ & $\begin{array}{l}0.63 \mathrm{a} \\
0.99 \mathrm{~b} \\
1.12 \mathrm{~b} \\
1.47 \mathrm{c} \\
1.67 \mathrm{c} \\
0.54 \mathrm{a}\end{array}$ \\
\hline & & & \multicolumn{3}{|c|}{ Analysis of Variance } \\
\hline Treatment & & & $* * *$ & $* *$ & $* * *$ \\
\hline
\end{tabular}

**,*** Significant at the 0.005 and 0.001 probability levels, respectively. $\dagger$ a,b All values within a column with no common letter are significantly different $(p<0.005)$.

At a constant concentration of $\mathrm{Zn}$ supply the $\mathrm{Zn}$ content of the plants decreased when 25 and $65 \mu \mathrm{mol} \mathrm{L}^{-1}$ of the ligand were added to 0.008 and $0.015 \mu \mathrm{mol} \mathrm{L}^{-1} \mathrm{Zn}$ treatments, respectively. The presence of the citrate had no effect on $\mathrm{Zn}$ concentration in the plants except at the highest addition to the $0.015 \mu \mathrm{mol} \mathrm{L}{ }^{-1} \mathrm{Zn}$ treatment, when $\mathrm{Zn}$ concentration decreased.

\section{Experiment 4}

All plants grown in the absence of citrate produced $\mathrm{Zn}$ deficiency symptoms whereas those in the presence of citrate were free of symptoms. The severity of the symptom increased with decreasing $\mathrm{pH}$.

Shoot dry matter of plants grown in the presence of citrate tended to be higher than for those grown in the absence and the difference in growth increased with $\mathrm{pH}$ (Table 6). The yield of plants from treatments with $\mathrm{pH}$ $>5.5$ were greater than anticipated from Exp. 1 (by comparing the ratio of yields at pH 5.2 and 4.6 in Exp. 1 with the ratio of yields at $\mathrm{pH} 6.3$ and 4.6 in Exp. 4). The moles per charge of $\mathrm{Zn}^{2+}$ and $\mathrm{Zncit}^{-}$separately accounted for 72 and $71 \%$ of the variation in shoot dry

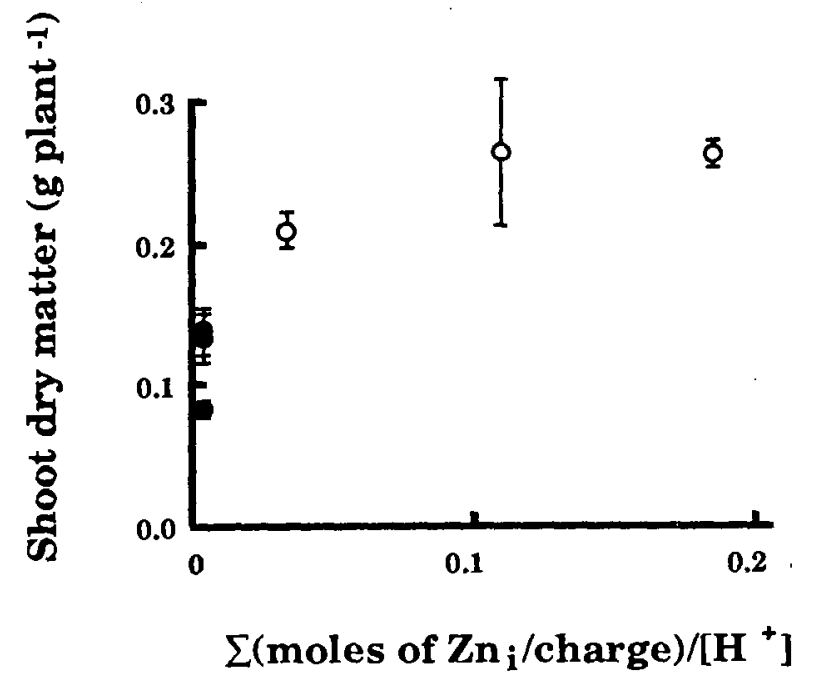

Fig. 4. The relationship between $\Sigma\left(\right.$ moles $Z n_{v} /$ charge)/ $\left[H^{+}\right]$and shoot dry matter of wheat plants in the absence or presence of $65 \mu \mathrm{mol} \mathrm{L}^{-1}$ of citrate at pH 3.7 to 7.1 .
Table 6. Experiment 4. Shoot dry weight, $\mathrm{Zn}$ concentration and $\mathrm{Zn}$ content of wheat plants grown in the presence (+) or absence $(-)$ of $65 \mu \mathrm{mol} \mathrm{L}^{-1}$ citrate, [cit $]$, and 0.015 $\mu \mathrm{mol} \mathrm{L}^{-1} \mathrm{Zn}$ in solution at various $\mathrm{pH}$.

\begin{tabular}{|c|c|c|c|c|}
\hline \multicolumn{2}{|c|}{ Treatments } & \multicolumn{3}{|c|}{ Shoots $\dagger$} \\
\hline$\left[\mathrm{cit}_{\mathrm{T}}\right]$ & pH & dry wt. & Zn conc. & Zn content \\
\hline$(\mu \mathrm{mol} \mathrm{L}-1)$ & & g plant ${ }^{-1}$ & $\mu \mathrm{g}^{-1}$ & $\mu \mathrm{g}$ plant $^{-1}$ \\
\hline \multirow[t]{2}{*}{$\begin{array}{r}0 \\
0 \\
0 \\
65 \\
65 \\
65 \\
65\end{array}$} & $\begin{array}{l}4.7 \\
4.5 \\
3.7 \\
6.3 \\
6.9 \\
7.1\end{array}$ & $\begin{array}{l}0.14 \mathrm{a} \\
0.20 \mathrm{ab} \\
0.15 \mathrm{a} \\
0.21 \mathrm{ab} \\
0.267 \mathrm{~b} \\
0.280 \mathrm{~b}\end{array}$ & $\begin{array}{c}12.56 \mathrm{a} \\
13.78 \mathrm{a} \\
9.28 \mathrm{bc} \\
17.48 \mathrm{~b} \\
18.28 \mathrm{~b} \\
18.58 \mathrm{~b}\end{array}$ & $\begin{array}{l}1.79 \mathrm{ab} \\
2.04 \mathrm{~b} \\
0.88 \mathrm{a} \\
3.58 \\
4.69 \mathrm{c} \\
5.02 \mathrm{c}\end{array}$ \\
\hline & & \multicolumn{3}{|c|}{ Analysis of Variance } \\
\hline Treatments & & NS & $* * *$ & $* * *$ \\
\hline
\end{tabular}

*** Significant at the 0.001 probability level, and $\mathrm{NS}=$ not significant. $\dagger \mathrm{a}, \mathrm{b}$ All values within a column with no common letter are significantly different $(p<0.005)$.

matter. The combined effect of the two $\mathrm{Zn}$ species, however, accounted for $87 \%$ of the variation. The shoot dry matter also correlated well with the ratio of moles per charge of $\mathrm{Zn}$ to $\mathrm{H}^{+}$(Fig. $4 ; r^{2}=0.79 ; y=A+B e^{-c x}$ ) and $\mathrm{Zn}_{\mathrm{T}} /\left[\mathrm{H}^{+}\right]\left(r^{2}=0.79 ; y=A+B e^{-\mathrm{cx}}\right)$.

Both $\mathrm{Zn}$ concentration and $\mathrm{Zn}$ content in plant shoots were higher in the presence of citrate than in the absence (Table 6). In the presence of citrate, $\mathrm{Zn}$ concentrations were similar at all $\mathrm{pH}$ values. In the absence of citrate, the concentration increased when $\mathrm{pH}$ changed from 3.7 to $4.5(p<0.05)$. In the presence of citrate, $\mathrm{Zn}$ content increased $(p<0.05)$ as $\mathrm{pH}$ rose from 6.3 to 6.9. In the absence of citrate, it increased $(p<0.05)$ when $\mathrm{pH}$ changed from 3.7 to 4.5 .

\section{All Experiments}

The $\mathrm{Zn}$ content and relative yield of wheat from Exps. 1 through 4 for data at $\mathrm{pH} \leq 5.5$ could be explained by a single curve when plotted against the ratio of the sum of moles per charge of $\mathrm{Zn}$ species and $\mathrm{H}^{+}$(Fig. $5 ; r^{2}=$ $\left.0.78 ; y=A+B e^{-c x}\right)$ and when plotted versus $Z_{\mathrm{n}_{\mathrm{T}}} /$ $\left[\mathrm{H}^{+}\right]\left(r^{2}=0.70 ; y=A+B e^{-c x}\right)$. Relative yield was estimated by assuming that maximum yield was obtained

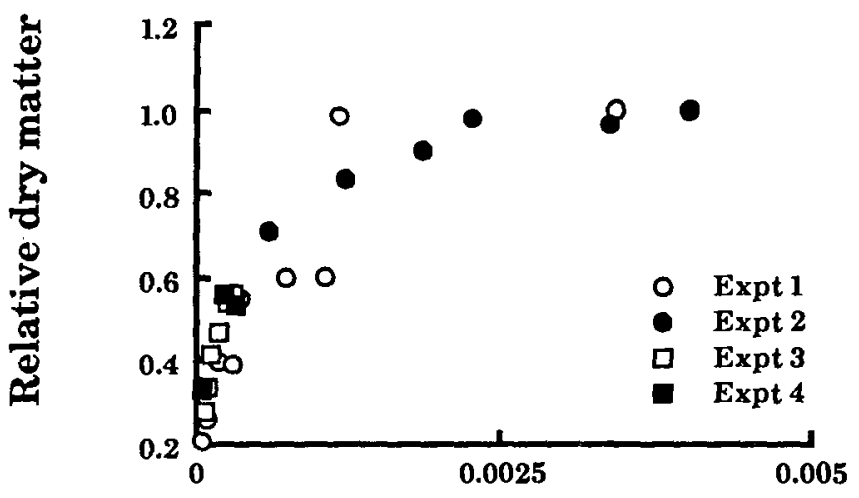

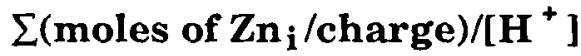

Fig. 5. The relationship between $\Sigma$ (moles $Z_{n} /$ charge)/ $\left./ H^{+}\right]$and relative dry matter of wheat plants from four experiments at $\mathbf{p H} \leq 5.5$. 
at $\mathrm{pH} 5.2$ or 5.5 at $0.015 \mu \mathrm{mol} \mathrm{L}^{-1} \mathrm{Zn}_{\mathrm{T}}$ and in the absence of citrate. For data from Exps. 3 and 4 , maximum yield was estimated by assuming it equalled the yield at $0.015 \mu \mathrm{mol} \mathrm{L} \mathrm{L}^{-1} \mathrm{Zn}_{\mathrm{T}}$ and $\mathrm{pH} 4.6$ or 4.7 divided by 0.557 . The fraction 0.557 was estimated from the yield at $\mathrm{pH} 4.7$ expressed as a fraction of the yield at pH 5.2 in Exp. 1 for a $\mathrm{Zn}$ supply of $0.015 \mu \mathrm{mol} \mathrm{L}^{-1}$.

\section{DISCUSSION}

Plants were able to take up $\mathrm{Zn}$ that was initially complexed with citrate. Plant growth and $\mathrm{Zn}$ uptake at $\mathrm{pH}$ $\leq 5.5$ was affected by $\mathrm{pH}$, the $\mathrm{Zn}$ supply and possibly the form of $\mathrm{Zn}$ species in solution. At $\mathrm{pH}>6.3$ another unidentified factor affected $\mathrm{Zn}$ uptake.

\section{Zinc Uptake in the Presence of Citrate}

In the presence of citrate, the correlation between $\Sigma$ (moles $\mathrm{Zn}_{\mathrm{i}} /$ charge) $/\left[\mathrm{H}^{+}\right]$and plant growth suggested that the number of charges on the species may affect the plants ability to take up $\mathrm{Zn}$. In the presence of citrate there were more moles per charge of $\mathrm{Zn}$ because more $\mathrm{Zn}$ was in the form of single-charge species $\left(\mathrm{Zncit}^{-}\right)$. Further experiments (Similar to Exp. 2) would have to be conducted to confirm this hypothesis. A bigger variation in $\mathrm{Zncit}^{-}$would be necessary as well as a constant solution $\mathrm{pH}$ and possibly a lower $\mathrm{Zn}$ supply.

The ratio $\mathrm{Zn}_{\mathrm{T}} /\left[\mathrm{H}^{+}\right]$was well correlated with plant growth possibly because the effect of $\mathrm{pH}$ on uptake in Exps. 3 and 4 was greater than the effect of citrate and hence the effect of citrate on $\mathrm{Zn}$ uptake was overshadowed by the $\mathrm{pH}$ effect. In Exp. 2, the high correlation with $\mathrm{Zn}_{\mathrm{T}} /\left[\mathrm{H}^{+}\right]$was partially a consequence of the regression being fitted through only three values of $x$ (two of the six and three of the six $x$ values were the same). In the case of the correlation between plant growth and $\Sigma$ (moles $\mathrm{Zn}_{\mathrm{i}} /$ charge) $/\left[\mathrm{H}^{+}\right]$, all six $x$ values were evenly spread along the fitted curve and hence no individual point had a marked effect on the $r^{2}$ value (Fig. 2).

The importance of the charge of a metal chelate on its absorption by plants has been suggested by DeKock and Mitchell (1957). The effect of charge characteristics of $\mathrm{Cu}$ chelate on the uptake of the element from nutrient solutions has also been shown for Italian ryegrass (Lolium multiflorum Lam.) and red clover (Trifolium pratense L.) (Iwasaki and Takahashi, 1989). On the other hand, the total concentration in soil solution extracts of micronutrients such as $\mathrm{Zn}$ and $\mathrm{Cu}$ was shown to be less important as far as the uptake by plants was concerned, particularly in the presence of a ligand (Halvorson and Lindsay, 1977; Minnich et al., 1987).

\section{Zinc Uptake in the Absence of Citrate}

The growth of wheat was controlled by $\mathrm{Zn}$ supply, the direct effect of $\mathrm{H}^{+}$on yield and the effect of $\mathrm{H}^{+}$on $\mathrm{Zn}$ uptake and hence yield. The concentration of total $\mathrm{Zn}$ in solution was not a good indicator of dry matter yield unless the $\mathrm{pH}$ of the nutrient solution was also considered.

At a constant concentration of $0.008 \mu \mathrm{mol} \mathrm{L}^{-1} \mathrm{Zn}$, plant growth was affected by all three factors (i.e. $\mathrm{Zn}$ supply, $\mathrm{H}^{+}$, and $\mathrm{H}^{+}$effects on $\mathrm{Zn}$ uptake). At 0.015 $\mu \mathrm{mol} \mathrm{L} \mathrm{L}^{-1} \mathrm{Zn}, \mathrm{H}^{+}$decreased plant growth directly by decreasing $\mathrm{Zn}$ uptake whereas at $0.05 \mu \mathrm{mol} \mathrm{L^{-1 }} \mathrm{Zn}$ the effect of $\mathrm{H}^{+}$on $\mathrm{Zn}$ uptake was decreased by the luxury supply of $\mathrm{Zn}$ and hence variations in wheat growth were mainly related to the direct effects of $\mathrm{H}^{+}$on yield. Increasing the $\mathrm{pH}$ from 4.0 to 4.6 had a greater effect on yield at a $\mathrm{Zn}$ supply of $0.015 \mu \mathrm{mol} \mathrm{L}^{-1}$ than at 0.05 $\mu \mathrm{mol} \mathrm{L}-1$ because two factors were limiting yield in the former case whereas mainly one factor was limiting yield at $0.05 \mu \mathrm{mol} \mathrm{L} \mathrm{L}^{-1}$. Nevertheless, the symptoms indicated that $\mathrm{H}^{+}$was still limiting $\mathrm{Zn}$ uptake at the two lower $\mathrm{pH}$ values even when there was a luxury supply of $\mathrm{Zn}$. The increase in yield when the $\mathrm{pH}$ increased from 4.0 to 4.6 at a $\mathrm{Zn}$ supply of $0.015 \mu \mathrm{mol} \mathrm{L^{-1 }}$ is greater than at 0.008 $\mu \mathrm{mol} \mathrm{\textrm {L } ^ { - }}$ because in the latter situation the plants are still restricted by an inadequate supply of $\mathrm{Zn}$.

At $\mathrm{pH} 5.2$ and $\mathrm{Zn}$ supplies greater than $0.008 \mu \mathrm{mol}$ $\mathrm{L}^{-1}$ neither $\mathrm{pH}$ nor $\mathrm{Zn}$ supply were limiting growth. However, at $0.008 \mu \mathrm{mol} \mathrm{L}^{-1}$, even though plants grown at this $\mathrm{pH}$ grew better than the plants at the other two lower pHs, they showed symptoms of $\mathrm{Zn}$ deficiency first. Dilution of $\mathrm{Zn}$ in the plants appeared to have occurred and been responsible for the earlier symptoms.

The free ion, $\mathrm{Zn}^{2+}$, has been suggested as the available form of $\mathrm{Zn}$ (Halivorson and Lindsay, 1977). However, in this present study, we could not correlate $\mathrm{Zn}^{2+}$ with the shoot dry matter, $\mathrm{Zn}$ content, or $\mathrm{Zn}$ concentration in the plants. This phenomenon may be partially attributable to an overriding influence of $\mathrm{pH}$ on $\mathrm{Zn}$ uptake.

The success of the introduction of the effect of $\mathrm{H}^{+}$ into the regression as a divisor factor to $\mathrm{Zn}_{\mathrm{t}}$ or the total moles per charge of $\mathrm{Zn}_{\mathrm{i}}$ is in agreement with the competition effect of $\mathrm{H}^{+}$as described earlier by Chaudhry and Loneragan (1972).

\section{Root Growth}

The response of the roots to $\mathrm{Zn}$ supply appeared to be $\mathrm{pH}$ dependent. At low $\mathrm{pH}$ (i.e. $\mathrm{pH} 4.0$ and 4.6) when the toxicity effect of $\mathrm{H}^{+}$was greatest, the roots did not respond to an increasing concentration of $\mathrm{Zn}_{\mathrm{T}}$. On the other hand, when the $\mathrm{H}^{+}$toxicity was absent at $\mathrm{pH} 5.2$, there was an increase in root growth with an increasing concentration of $\mathrm{Zn}_{\mathrm{T}}$. Shoot growth as influenced by $\mathrm{Zn}_{\mathrm{T}}$ appeared to be independent of root growth because it responded to an increasing $Z_{n_{T}}$ despite the absence of a growth response by the roots.

Hydrogen ions did not affect the plants' ability to take up $\mathrm{Zn}$ as much as they affected the plants' ability to grow shoots and roots. The concentration of $\mathrm{Zn}$ in the plants grown at a deficient supply did not differ as $\mathrm{pH}$ increased even though shoot and root growth increased. On the other hand, the $\mathrm{Zn}$ concentration in plants decreased as $\mathrm{pH}$ increased at adequate and luxury supplies of $\mathrm{Zn}$ because $\mathrm{Zn}$ uptake was not hindered by $\mathrm{H}^{+}$at the lower $\mathrm{pH}$ values to the same extent as shoot. and root growth.

\section{Root/Total Growth Ratio}

At each $\mathrm{pH}$, the root/total growth ratio was highest at the lowest $\mathrm{Zn}$ supply. This may indicate that the plants acquired as much as possible when the supply was low in order to maintain their internal concentration. When Zn supply became more abundant, plants then developed more shoot and hence the ratio went down. Carroll and 
Loneragan (1968) also found a greater root/shoot ratio at lower $\mathrm{Zn}$ supply in wheat and several other plants.

These results indicated the presence of organic ligands such as citrate in the rhizosphere may affect $\mathrm{Zn}$ uptake by wheat, but the effect will depend on $\mathrm{pH}$ and $\mathrm{Zn}$ supply.

\section{ACKNOWLEDGMENTS}

We are grateful to Prof. A.D. Robson and Mr. K. Snowball for technical advice. The research was funded by the Western Australian Wheat Committee.

\section{REFERENCES}

Cabaniss, S.E. 1987. TITRATOR: An interactive program for aquatic equilibrium calculations. Environ. Sci. Technol. 21:209 210.

Carroli, M.D. and J.F. Loneragan. 1968. Response of plant species to concentrations of zinc in solution 1 . Growth and zinc content of plants. Aust. J. Agric. Res. 19:859-868.

Chairidchai, P. and G.S.P. Ritchie. 1990. Zinc adsorption by a lateritic soil in the presence of organic ligands. Soil Sci. Soc. Am. J. 54:1242-1248.

Chaudhry, F.M. and J.F. Loneragan. 1972. Zinc absotption by wheat seedlings and the nature of its inhibition by alkaline earth cations. J. Expt. Bot. 23:552-560.

DeKock, P.C. and R.L. Mitchell. 1957. Uptake of chelated metals by plants. Soil Sci. 84;55-62.
Ewing, M.A. and A.D. Robson. 1991. The use of MES buffer in early nodulation studies with annual Medicago species. Plant Soil 131:199-206.

Halvorson, A.D. and W.L. Lindsay. 1972. Equilibrium relationships of metal chelates in hydroponic solutions. Soil Sci. Soc. Am. Proc. 36:755-761.

Halvorson, A.D. and W.L. Lindsay. 1977. The critical $\mathrm{Zn}^{2+}$ concentration for corn and the nonabsorption of chelated zinc. Soil Sci. Soc. Am. J. 41:531-534.

Haynes, J.L. and W.R. Robbins. 1948. Calcium and boron as essential factors in the root environment. J. Am. Soc. Agron. 40:795-803.

Hewett, E.J. 1952. Sand and water culture methods used in the study of plant nutrition. Tech. Commun. Commonw. Bur. Hor tic. Plant Crops. no. 22. Commonwealth Agricultural Bureaux, Farnham, UK.

Iwasaki, K. and E. Takahashi. 1989. Effects of charge characteristics of $\mathrm{Cu}$-chelates on the $\mathrm{Cu}$ uptake from solution by Italian ryegrass and red clover. Soil Sci. Plant Nutr. 34:145-150.

Johnson, C.M. and A. Ulrich. 1959. Analytical methods for use in plant analysis. California Agric. Exp. Stn. Bull. no. 766.

Lindsay, W.L. 1979. Chemical equilibria in soils. John Wiley and Sons, New York.

Martell, A.E. and R.M. Smith. 1977. Critical stability constants: other organic ligands. Vol. 3, Plenum Press, New York.

Minnich, M.M., M.B. McBride and R.L. Chaney. 1987. Copper activity in soil solution: II. Relation to copper accumulation in young snapbeans. Soil Sci. Soc. Am. J. 51:573-578.

Stevenson, F.J. and M.S. Ardakani. 1972. Organic matter reaction involving micronutrients in soils. p. 79-114 In J.J. Mortvedt et al. (ed.) Micronutrients in agriculture. SSSA, Madison, WI. 